\title{
DEFEATING SHAREHOLDERS' LOANS: LARONGE REALTY LTD. V. GOLCONDA INVESTMENTS LTD. ET AL
}

by R. W. EWASIUK*

In Laronge Realty Ltd. v. Golconda Investments Ltd. ${ }^{1}$ the British Columbia Court of Appeal has rendered a troublesome decision which could have unfortunate implications for shareholders who have made genuine loans to their corporations.

At issue in that case was the ability of shareholders to rank as unsecured creditors in respect of monies they had advanced to their company. Of course, it is most common for shareholders in non-distributing companies to invest money by way of loan rather than by way of share capital. The obvious advantages in doing so are that the monies can be returned to the shareholders without the necessity of having to satisfy the various solvency tests set out in corporate legislation ${ }^{2}$ and that the shareholders stand some chance at least of recovering a portion of their investment in the event of a failure. These loans are seldom documented by anything other than book entries. Elaborate loan agreements are rare. However, there is most often a clear intention that the advances be regarded as loans.

In keeping with the most fundamental of corporate law concepts, it has always been the case that a shareholder, as an individual distinct from his corporation, ranks with other creditors in respect of monies owed to him. The fact that a creditor is also a shareholder is irrelevant. ${ }^{3}$ There are undoubtedly occasions where this gives the appearance at least of inequity (particularly where the shareholders have secured their position) but the ability of shareholders to legitimately rank with other creditors under the law hasn't been seriously questioned since Salomon v. Salomon \& Co."

The trouble with the Laronge case is not that it has purported to overrule this principle. In form at least it has not. The problem is in the methods the Court has employed in getting around it and that it has employed these methods without the facts to support them. At the very least, the case imposes a heavy onus on shareholders to prove the validity of their loans and has made the onus difficult if not at times impossible to discharge.

It may be that Laronge will be forgotten. It may be that if raised as authority in future cases, it will be distinguished on its facts. If raised in Alberta it may simply be disagreed with. However, the trial Justice was the Chief Justice and the Court of Appeal was unanimous in upholding his decision. Furthermore, it seems quite likely that the next time such a case comes before the courts there will again be a creditor who appears to have been hard done by and there will again be a resulting bias against the

* Of the firm Reynolds, Mirth, and Coté, Edmonton, Alberta.

1. (1986) 7 B.C.L.R. (2d) 90 (C.A.).

2. See, in particular, Business Corporations Act, S.A. 1981, c. B-15, ss. 32, 34 \& 36. This is not often a major advantage. The ability of a corporation to legitimately repay loans to its shareholders is itself subject to various statutes respecting preferences.

3. There are, of course, exceptions where the monies are due to him in his capacity as shareholder (such as monies due on the redemption of shares).

4. [1897] A.C. 22. 
shareholders. The danger, then, is that this case will come to stand for something.

\section{THE FACTS}

The facts in the Laronge case can be simplified without distorting the principals involved. The company, Richmond Breweries Ltd., had liquidated its assets and assigned itself into bankruptcy. In addition to the shareholders, the company had left a major unsatisfied creditor (the "Creditor"). The question was whether the shareholders' loans were to rank with or behind the claims of the Creditor.

There may, of course, have been facts that were known to the Court but not expressed in the report. However, from the report it appears that the only relevant facts ${ }^{5}$ (put forward by way of affidavit evidence) were as follows:

1. Monies had actually been advanced to the company by the shareholders.

2. The books of the company showed that the monies were advanced as loans. There was no evidence that these book entries were anything but genuine.

3. There was no evidence of an express agreement as to how these advances were to be repaid, at least prior to bankruptcy.

4. The monies were initially advanced in proportion to the holdings of the various shareholders. Later in time some shareholders advanced more than others.

5. Subsequent to the bankruptcy, the shareholders entered into an agreement (unfairly termed the "gang-up" agreement by the trial Justice) respecting the payment of expenses of this litigation and the ultimate distribution of the proceeds. Both levels of the court found significance in two of the preambles to that agreement. They read as follows:
"AND WHEREAS the parties agreed that they would commit funds from time to time for the needs of the corporation in proportion to their shareholdings and that all parties have committed from time to time Shareholders Loans.
AND WHEREAS the parties hereto advanced claims to the Receiver in respect of their Shareholders Loans and Advances and they now wish to make an arrangement to pool those claims for the purposes of having the mutual obligations between the Shareholders adjusted to reflect the original Agreement to share in accordance with their respective shareholdings in the said Richmond Breweries Ltd"'

These paragraphs were referred to in the judgment and will be referred to here as the "second preamble" and the "fourth preamble" respectively.

5. There are other facts which, although irrelevant, undoubtedly make the result appear more equitable and perhaps in the minds of some, more understandable. The company had sold its only asset of real value (land) through the efforts of the Creditor, a realtor. The company refused to pay the realtor its commission. The realtor successfully sued and on the day of judgment the company assigned itself into bankruptcy. The shareholders argued that the realtor had to rank with the shareholders in the estate. Had the shareholders been successful, the realtor's pro rata share would have been nominal. 


\section{THE ARGUMENTS}

The shareholders put forward the obvious argument that the monies they had advanced were legitimate loans and that they had no lesser right to the bankrupt's estate than the Creditor.

Twio distinct arguments were put forward in support of the Creditor's position although the two were often blurred. The first argument was that if the advances were loans then Section 110 of the Bankruptcy Act applied so as to postpone the shareholders' loans to the claims of the unsecured creditors. The second argument was that the shareholders' advances were not loans at all but were advances of capital.

\section{A. BANKRUPTCY ACT}

\section{Section 110 of the Bankruptcy Act ${ }^{6}$ reads as follows:}

110. Where a lender advances money to a borrower engaged or about to engage in trade or business under a contract with the borrower that the lender shall receive a rate of interest varying with the profits or shall receive a share of the profits arising from carrying on the trade or business, and the borrower subsequently becomes bankrupt, the lender of the money is not entitled to recover anything in respect of the loan until the claims of all other creditors of the borrower have been satisfied. (emphasis added)

Section 110 is an extension, or at least a special case, of the principle that a person who advances capital to a business puts that capital at risk. That is to say, in circumstances where the lender is actually engaged in a joint venture with the borrower, the loan will be treated as capital. ${ }^{7}$ The section clearly contemplates the situation where the lender is to participate in the profits of the business in consideration of the loan. This sharing in profits must arise out of the contract of loan. Section 110 does not single out shareholders nor does it say that it could not apply to shareholders in appropriate circumstances. However, clearly it would apply only to a shareholder where the shareholder had entered into some form of common adventure with his corporation, although in such event he would be doing so in his capacity as an adventurer and not in his capacity as shareholder.

However, both the Trial and Court of Appeal level held that Section 110 applied. Their findings are, with respect, quite unsupportable. There was, first of all, nothing in the facts to suggest that any such contract had been entered into at all. In fact, the Court seems to make a point out of the fact that there were no agreed terms of compensation for the loans, stating: ${ }^{8}$

There was no evidence of any promise by the company to repay other than whatever might be inferred from the entry on the books. There was no evidence of any terms of repayment having been agreed to in any form or of any agreement having been made to pay interest on these advances.

How then did the court find that shareholders had a contract with their corporation pursuant to which the shareholders were to receive a share of the profits? The reasoning is not at all clear. The Court does make mention

6. R.S.C. 1970 , c. B-3.

7. The Partnership Act R.S.A. 1980, c. P-2, s. 5 has similar effect. That section provides that where, in the consideration of a loan, a lender is to participate in the profits of the borrower the lender must rank behind unsecured creditors.

8. At 93. 
of the "fourth preamble" and some clue to the reasoning may be found in the following quote $e^{9}$ taken from the oral judgment of the trial Justice:

The second and fourth preambles of the pooling agreement or what I refer to as the gangup agreement make it clear that these parties were shareholders and agreed to put up money as required and not for further shares. I have serious doubts the funds were put up as shareholders' loans. The funds were committed for the needs of the Corporation. The fourth preamble talks about sharing in the brewery which in substance is no different than lending under s. 110 on arrangement that they would share in profits. That is what I think they mean when they say shareholders. Repayment would come out of the profits of the company.

What the learned Trial Justice actually meant here is unclear. On the one hand he states that he doubts that the advances are loans. On the other, he says that they are loans to which Section 110 applies. Emphasis is placed on the preambles but no explanation is given as to how exactly they evidence anything other than the position put forward by the shareholders.

Unfortunately, the case report does not set out the body of the "gangup" agreement in its entirety. It would appear, however, that its intent was the establishment of a format for the distribution of the ultimate proceeds if the shareholders were successful. The proceeds would first be utilized to pay out legal fees ${ }^{10}$ and the balance would then be distributed to the shareholders in proportion to their outstanding loans. There doesn't appear to be anything more to the agreement than that. While the courts at both levels placed much emphasis on it the agreement was probably irrelevant.

There are four possible lines of reasoning behind the comments of the learned trial Justice none of which is particularly satisfactory. The first possible line of reasoning is that because the shareholders subsequently entered into an agreement to share in the leftover assets of the liquidated company (to recover a portion of their loans) this subsequent agreement was a contract "to share in the profits of the corporation". If this is the reasoning then, with respect, it is quite wrong. An agreement amongst shareholders as to how to repay loan principal out of proceeds that a Court would have said (if the shareholders were successful) were available for that purpose is hardly an agreement to share in profits. In any event, it is clear that this was not an agreement made in connection with the advances themselves as Section 110 contemplates. Further, this was an agreement made subsequent to the bankruptcy and not vice versa.

A second possible line of reasoning is based on the finding that the shareholders had always intended that the principal on these loans be repaid out of the "profits" of the company. To the extent that the word "profit" means monies not immediately necessary for the company's operations, this may very well have been the case. In fact, you can probably say that of any loan. However, s. 110 clearly intends that sharing of profits be something other than on a return of principal." The section contemplates a share out of profits in consideration of the loan itself in the same way that interest is paid in consideration of the loan. Indeed, if this second

9. At 93.

10. The lawyers who had defended the action for the creditors' commission were also unsecured creditors in respect of their legal fees. These fees would be paid as well as the fees of the present action.

11. Repaying loans out of "profits" is a contradiction in terms anyway. 
line of reasoning were correct, then banks and other creditors would have a great deal to worry about.

A third possibility is that because the lenders were shareholders, and because shareholders have a right to participate in the profits of the company they are lenders who are to share in the profits. That is to say that what you have here is a group of people who, having lent money to the company, have some vague and undefined expectation of sharing in the ultimate profits. Of course, if this argument had any substance it would be impossible for a shareholder to safely advance a loan to a company regardless of how well documented the loan was and how genuine it was. The fact that the shareholders have made loans in proportion to their shareholdings shouldn't make any difference. However, shareholders participate in profits, as shareholders, through dividends. ${ }^{12}$ Clearly, the entitlement to dividends is totally independent of an entitlement to compensation for loans. A shareholders' entitlement to profits (i.e. to dividends) does not arise out of a "contract" as contemplated by s. 110 .

The fourth, and most likely, possibility is based on a finding that the shareholders had embarked on a common adventure with the company and the company and the shareholders would share in the profits of their common enterprise. In fact, this appears to be the logic employed by the Court of Appeal who found "that this was a business carried on for the joint benefit of the shareholders and the company." ${ }^{3}$ If the facts supported such a finding, then $\mathrm{s.110}$ might well have had application. The problem is that the facts could not support such a finding. There is a significant difference between the (rare) situation where shareholders carry on an enterprise in joint venture with their company and the situation where a company carries on an enterprise by itself and the shareholders benefit through dividends. In this case, the company was the sole owner of the property in question. Presumably (there was no evidence to the contrary) any revenues realized from the sale or the operation of the property would be the company's. Presumably (again there was no evidence to the contrary) these revenues would be utilized for future business needs or distributed to the shareholders by way of repayment of the loans (which properly speaking could not be termed a repayment out of "profits"). Presumably, if there was a profit, it would be distributed by dividend. There was no evidence of any other arrangement to share in profits. The only facts upon which the Court could have based its finding was that the shareholders had loaned monies to the company and happened to do so in proportion to their shareholdings. If the mere act of loaning money to a company makes a shareholder a joint venturer or, worse, a partner of his corporation then there has indeed been a radical change in the law.

\section{B. ADVANCES AS CAPITAL}

If $s .110$ could not be applied, then the Court of Appeal was prepared to find that the advances were made as advances of capital. Capital cannot be repaid until the creditors have been satisfied. The Court of Appeal referred to this as a "common law rule" and cited the Supreme Court of Canada

12. Or through the distribution of a surplus in a winding up.

13. At 95. 
decision in Sukloff v. A.H. Rushforth \& Co. ${ }^{14}$ in support of the proposition that this was part of Canadian law. ${ }^{15}$

Again, the finding that the advances were made as capital ${ }^{16}$ and not as loans was insupportable on the facts. Whether advances are to be capital or are to be loans is primarily a matter of agreement between the corporation and the shareholders making the advance - it is, if you like, a matter of intent. If the advances were intended to be capital then they are capital. If they were intended to be loans then they are loans. ${ }^{17}$ One would have thought that genuine book entries characterizing the advances as loans would be all but conclusive that the advances were intended as loans. The fact that specific terms regarding repayment were not agreed to ${ }^{18}$ was an indication of the understandable flexibility of the shareholders making the advances but very little more. In fact the lack of an agreement regarding how the profits would be shared supported the shareholders' position even more.

The Court again puts great emphasis on the infamous "fourth preamble". The reference to an "original agreement" where the shareholders were "to share in accordance with their respective shareholdings in the said Richmond Breweries Ltd"' is said to be "entirely inconsistent with the suggestion that the advances were essentially in the nature of a loan".19 Why the court feels there is such an inconsistency is not clear. The intention of shareholders to loan monies from time to time in proportion to their shareholdings as the company's needs require is neither unusual nor sinister. In an ideal world the shareholders could have gone to a Bank instead and would doubtless have preferred to do so. As it was they were obliged to loan their own monies to the company and felt, understandably, that any monies left over on liquidation should be distributed rateably. The wording of the "gang-up" agreement may have been mildly unfortunate but it should not have had the devastating effect it did and, in fact, should have been largely ignored.

There is little authority relied on in support of the Court's position. The Court does make reference to one other decision, namely the English decision in Re Meade ${ }^{20}$ also quoted in the Sukloff case. Unfortunately, the Court relies on the headnote in outlining the facts which it finds to be "very close in its essential particulars" ${ }^{21}$ to the facts at hand. In fact, the facts in

14. [1964] S.C.R. 459.

15. The Sukloff case, also deals with the predecessor to section 110 of the Bankruptcy Act and the predecessor of the Ontario equivalent of section 5 of the Alberta Partnership Act. The court held that an agreement to share in profits for the purpose of securing a loan made previous in time does not fall within these sections.

16. The Court did not appear to be suggesting that this was share capital. In fact the Trial Justice (see quote, supra.) states that the monies were put up "as required and not for further shares". Apparently, the Court viewed the advances as being capital in a more general sense.

17. And, for purposes of characterizing the advance it should not matter in the slightest that other creditors will be prejudiced even if the shareholders intended that they be prejudiced and even if the shareholders rubbed their hands together and chuckled about it.

18. Other than the obvious implication that the advances were not intended as gifts and were to be repaid at some point in time.

19. At 96 .

20. [1951] Ch. 774, 2 All E.R. 168.

21. At 95 . 
Meade were very different. Suffice to say that in Meade there was no evidence that the monies advanced had never been regarded by the parties involved as loans and in fact there was significant evidence to the contrary. In this case there was evidence that the parties regarded the advances as loans and, aside from the unsupportable conclusions drawn from the "gang-up" agreement and the fact that the lenders were also shareholders, there was no evidence to the contrary.

\section{EQUITY}

One other disturbing aspect of this case is in the Court's mention, ${ }^{22}$ with what appears to be approval, of a statement out of an American bankruptcy case. ${ }^{23}$ The statement is to the effect that where a claimant in bankruptcy "has violated the rules of fair play and good conscience, the claim may be disallowed". Stated in such broad terms this is, of course, a principle that is alien to Canadian law. The idea that a court, even in a bankruptcy matter, can (legitimately) ignore rules of law simply because the particular judge feels that the claimant is unprincipled or that the result will otherwise be unfair, is novel indeed. Fortunately, the comments are dicta. However, in stating that the Court need not decide that point, the Court does make the following, illuminating, comment: ${ }^{24}$

I would not wish to say anything which would encourage the view that the Court does not
have a long armss to prevent the kind of grossly unjust results which I think would have
been achieved had the [shareholders] succeeded in the position they took.

Obviously, the Court had taken a very dim view of what the shareholders were attempting to accomplish. One hopes that if this case is ever relied on in Alberta the underlying motivation will not go unnoticed.

\section{CONCLUSION}

It is difficult to find a ratio to the Laronge decision. It may be that the Laronge decision has no application outside the narrow facts of the case. However, if there is a ratio, there would appear to be a number of possibilities, including the following:

1. In bankruptcy, shareholders' loans will always rank behind the claims of unsecured creditors.

2. In bankruptcy, shareholders' loans that had been made in proportion to shareholdings, will always rank behind the claims of unsecured creditors.

3. Shareholders' advances will be regarded as capital unless there is strong evidence to the contrary.

4. Shareholders' advances, if they are made in proportion to shareholdings, will be regarded as capital unless there is strong evidence to the contrary.

22. At 96 and 97.

23. Pepper v. Litton (1939) 308 U.S. 295.

24. At 97.

25. This "long arm" is well known to lawyers who have practised litigation. It is what leads to the bad law that comes out of hard cases. It is also one of the reasons why some practitioners argue that future solicitors would be wise to practice a little litigation before specializing. 
At the very least the case does illustrate that shareholders' loans are prone to attack unless some considerable care is taken. The practitioner may wish to consider the following:

1. Shareholders' loans should be documented by promissory notes or by some other form of loan agreement as and when the advances are made. It is dangerous to rely upon book entries, financial statements or other forms of non-contractual evidence.

2. Even when shareholders have secured their position by assignment of book debts, by debenture or by some other form of "general" security, the debenture will only secure those advances that are themselves found to be loans. Such security will not often evidence the loans themselves, and hence security of that nature may be insufficient of itself.

3. Shareholders would be wise to establish payment arrangements at the time of the loan. At the very least, it should be stated that the loans are repayable on demand if that is the intention.

4. Shareholders should be extremely careful about the kind of interest or other consideration to be paid for the loan. For example, it is common practice for directors to resolve from time to time to pay a rate of interest that loosely tracks the fortunes of the company. If the company is not doing well, no interest is paid. If the company can afford it, interest might be paid on the loans after all. While the payment of interest in these situations might properly be characterized as consideration for not demanding the loans and while there is no contractual obligation to pay any interest all, a court like that in the Laronge case would find little difficulty holding that such an arrangement was one where interest varied with profits. It could also be taken as further evidence that the "loan" was actually an advance of capital. The fact that the loan is secured may not further the shareholders' position in the face of $s .110 .{ }^{26}$ Hence, a fixed interest rate would be preferable even if, by documented agreement, it were varied from time to time.

26. Although, seen. 13. 